\title{
Analisis Kemampuan Koneksi Matematis Ditinjau dari Tipe Kepribadian Sanguinis dan Melancholis Siswa SMP
}

\author{
Farida Rahmaningtyas*, Heni Purwati, Aryo Andri Nugroho \\ Universitas PGRI Semarang \\ *faridatyas43@gmail.com
}

\begin{abstract}
ABSTRAK
Tujuan dari penelitian ini adalah untuk mengetahui kemampuan koneksi matematis yang ditinjau dari tipe kepribadian sanguinis dan melancholis siswa SMP. Penelitian ini menggunakan jenis penelitian kualitatif deskriptif. Pengambilan data dilakukan pada siswa SMP Negeri 22 Semarang kelas VII F pada tahun ajaran 2019/2020. Fokus pemilihan subjek dalam penelitian ini yaitu pada tipe kepribadian sanguinis dan melancholis. Penilitian ini menggunakan teknik pengumpulan data berupa angket tipe kepribadian, tes, wawancara serta dokumentasi untuk mengabadikan semua halhal penting yang dilakukan saat penelitian. Teknik analisis data yang digunakan dalam penelitian ini adalah reduksi data, penyajian data, dan menarik kesimpulan atau verifikasi. Validasi data menggunakan triangulasi teknik. Hasil penelitian dianalisis mengacu pada indikator kemampuan koneksi matematis yaitu: 1) menemukan hubungan dari berbagai representasi tentang konsep dan prosedur matematika; 2) memahami hubungan antar topik dalam matematika; 3) mampu menggunakan matematika dalam menyelesaikan masalah kehidupan sehari-hari. Hasil dari penilitian ini menunjukkan bahwa subjek sanguinis mampu memenuhi semua indikator dan subjek melancholis mampu memenuhi dua indikator yaitu indikator ke 1 dan 2.
\end{abstract}

Kata kunci: analisis, kemampuan koneksi matematis, tipe kepribadian sanguinis, melancholis.

\begin{abstract}
The purpose of this study was to determine the mathematical connection ability in terms of sanguinis and melancholis personality types of junior high school students. This research uses descriptive qualitative research. Data collection was carried out on student of SMP Negeri 22 Semarang class VII $F$ in the 2019/2020 scholl year. The focus of subject selection in this study is sanguinis and melancholis personality types. This research uses data collection techniques in the form of personality type questionnaires, tests, interview and documentation to perpetuate all important things that are done during the research. Data analysis techniques used in this study were data reduction, data presentation, and drawing conclusions or verification. The data validation used technical triangulation. The research results were analyzed referring to the indicators of mathematical connection ability, namely: 1) Finding the relationship between various representations of mathematical concepts and procedures; 2) Understanding the relationship between topics in mathematics; 3) Able to use mathematics in solving daily life problems. The results of this study indicate that the sanguinis subject is able to fulfill all indicators and the melancholis subject is able to fulfill two indicators, namely indicators 1 and 2.
\end{abstract}

Keywords: analysis, mathematical connection ability, personality type sanguinis, melancholis. 


\section{PENDAHULUAN}

Keberadaan matematika sangatlah penting di dunia modern, hal itu dapat dilihat dari halhal yang berada di sekitar kita berhubungan dengan matematika. "Mathematics, it is widely understood, plays a key role in shaping how individuals deal with the various spheres of private, social, and civil life" yang berarti matematika dipahami secara luas, mempunyai peran penting dalam membentuk bagaimana individu menghadapi berbagai bidang kehidupan pribadi, sosial, dan bermasyarakat (Anthony \& Walshaw, 2009). Suatu kegiatan pembelajaran dimana siswa dapat mendefinisikan bagaimana cara menyelesaikan suatu permasalahan yang saling berhubungan, dan siswa dapat menerapkan pengetahuan yang diperoleh dalam memecahkan suatu masalah ke masalah lain merupakan koneksi matematis (Lappan et al., 2002). Kemampuan koneksi matematis menjadi sangat penting dapat membantu penguasaan pemahaman konsep dan membantu menyelesaikan pemecahan masalah melalui keterkaitan antar konsep matematika dan antara konsep matematika dengan konsep dalam disiplin lain (Rustina \& Anisa, 2018).

Pentingnya pengembangan kemampuan koneksi matematis siswa ini tidak dibarengi dengan kenyataan yang terjadi. Hasil penelitian yang dilakukan oleh Saminanto \& Kartono (2015), menunjukkan bahwa hasil rata-rata kemampuan koneksi antar konsep dalam satu materi tinggi yaitu 94\%, koneksi antar topik dalam matematika sedang yaitu 55\%, koneksi antar konsep matematika dan sains lainnya adalah 40\% dan hubungan antara matematika dan kehidupan sehari-hari adalah $2 \%$. Secara umum, kemampuan koneksi matematis rendah yaitu 34,96\%. Penelitian yang sama juga dilakukan oleh Warih, Parta, dan Rahardjo (2016), diperoleh hasil bahwa masih rendahnya kemampuan koneksi matematis siswa, hal itu ditunjukan karena siswa tidak melakukan pengoneksian secara maksimal dalam tes awal kemampuan koneksi matematis dan pada konsep teorema pythagoras siswa tidak dapat menerapkan konsep yang telah dipelajari sebelumnya.

Indikator yang digunakan untuk menganalisis kemampuan koneksi matematis siswa SMP kelas VII adalah menurut Sumarmo (Rohendi \& Dulpaja, 2013), sebagai berikut: (1) Menemukan hubungan dari berbagai representasi tentang konsep dan prosedur matematika. (2) Memahami hubungan antar topik dalam matematika. (3) Mampu menggunakan matematika dalam penyelesaian masalah dalam kehidupan sehari-hari.

Perbedaan tingkah laku setiap individu dapat mempengaruhi proses berpikir siswa. Dimana terdapat siswa yang terlihat aktif dan ada juga siswa yang terlihat pasif. Pengaruh kepribadian yang berbeda dapat mempengaruhi perbedaan tingkah laku antar individu. Menurut Widiantara dan Herdiyanto (2013), kepribadian merupakan karakteristik seseorang yang menyebabkan munculnya konsistensi perasaan, pemikiran dan perilaku. Perilaku, pemikiran, dan pribadi seseorang tidaklah sama antara satu dengan yang lainnya. Hasil penelitian yang berhubungan dengan kepribadian telah dilakukan oleh Agustina, Sujadi dan Pangadi (2013) menunjukkan bahwa siswa dengan tipe sanguinis, choleris, melancholis, phlegmatis mempunyai proses berpikir yang berbeda dalam menyelesaikan masalah. Hasil penelitian yang dilakukan oleh Fitria dan Siswono (2014) menunjukkan bahwa setiap tipe kepribadian (sanguinis, choleris, melancholis, phlegmatis) mempunyai keterampilan berpikir kreatif yang berbeda-beda dalam memecahkan masalah. 
Kepribadian merupakan suatu ciri khas tingkah laku seseorang (Arifianti \& Ismail, 2018). Kepribadian merupakan organisasi dari sikap-sikap yang dimiliki sebagai latar belakang terhadap perilakunya (Bulu, Budiyono, \& Slamet, 2015). Sedangkan menurut Adolf Heuken S.J dalam (Jaenudin, 2015), menyatakan "kepribadian adalah pola menyeluruh semua kemampuan, perbuatan serta kebiasaan seseorang, baik yang jasmani, mental, rohani, emosional maupun yang sosial. Semuanya ini telah ditata dalam caranya yang khas di bawah beraneka pengaruh dari luar. Pola ini terwujud dalam tingkah lakunya, dalam usahanya menjadi manusia sebagaimana dikehendakinya". Kepribadian merupakan kesatuan yang kompleks, yang terdiri atas aspek psikis dan fisik yang menentukan ciri-ciri yang khas dari seseorang dalam menyesuaikan diri dengan lingkungannya.

Ada banyak teori yang dapat digunakan dalam memahami tipe kepribadian siswa. Salah satu teori yang sering digunakan dan dikembangkan adalah teori kepribadian Tipologi Hippocrates - Galenus. Menurut Tipologi Hippocrates - Galenus, kepribadian digolongkan menjadi empat yaitu : choleris, sanguinis, melancholis dan phlegmatis (Maftuh, 2015). Dalam penelitian ini tipe kepribadian Tipologi Hippocrates-Galenus yang digunakan adalah tipe kepribadian sanguinis dan melancholis. Sanguinis adalah tipe kepribadian yang dijuluki sebagai "si populer" karena sangat persuasif dan selalu ingin terkenal, tipe melancholis dijuluki sebagai "si sempurna" karena bersifat perfeksionis dan serba teratur (Kadir, 2015).

Pada umumnya seorang sanguinis memiliki tingkah laku suka berbicara, bersemangat, penuh rasa ingin tahu, kreatif dan inovatif, mudah bergaul (Otaviana \& Susiaty, 2017). Menurut Littauer (Fitria \& Siswono, 2014), seorang yang memiliki kepribadian sanguinis dilihat dari segi pekerjaan mempunyai ciri-ciri sukarelawan dalam bekerja, memikirkan hal-hal baru, terlihat hebat dipermukaan, inovatif dan kreatif, mempunyai energi dan antusiasme, memulai dengan cara yang cemerlang, dapat mengilhami orang lain agar ikut bekerja. Littauer dan Sweet (2016) mendefinisikan sanguinis adalah orang yang bersemangat, suka bersenang-senang, optimis, pelupa, dan pendongeng yang memikat, orang ini berfokus pada diri sendiri dan pelupa.

Seorang melancholis memiliki sifat tekun, perasa terhadap orang lain, penuh pikiran, gigih dan cermat (Otaviana \& Susiaty, 2017). Selain itu seorang melancholis menampilkan kepribadian yang cenderung kurang ceria atau dengan kata lain sedikit lebih serius (Kadir, 2015). Menurut Littauer (Fitria \& Siswono, 2014) Seorang yang berkepribadian melancholis dilihat dari pekerjaan mempunyai ciri-ciri terjadwal, perfeksionis, memiliki standar tinggi, terperinci, gigih dan cermat, terorganisir, teratur dan rapi, ekonomis, kreatif dalam memecahkan masalah, menyelesaikan apa yang dimulai, menyukai diagram, bagan, grafik, dan daftar.

Berdasarkan hal-hal yang telah dijelaskan di atas maka peneliti tertarik untuk melakukan penelitian yang berkaitan dengan kemampuan koneksi matematis ditinjau dari tipe kepribadian sanguinis dan melancholis siswa SMP. Tujuan dari penelitian ini adalah untuk mengetahui kemampuan koneksi matematis siswa berdasarkan tipe kepribadian sanguinis dan melancholis.

\section{METODE}

Penelitian ini termasuk jenis penilitian kualitatif deskriptif. Pelaksanaan penelitian ini pada semester gasal tahun ajaran 2019/2020 di SMP Negeri 22 Semarang. Sedangkan pengambilan data penelitian dilaksanakan pada tanggal 20 Agustus 2019 hingga 27 September 2019. Teknik sampling yang digunakan dalam penelitian ini adalah purposive sampling. 
Penelitian ini dilakukan di kelas VII F SMP Negeri 22 Semarang. Subjek yang digunakan dalam penelitian ini adalah satu siswa bertipe kepribadian sanguinis dan satu siswa bertipe kepribadian melancholis.

Teknik pengumpulan data yang digunakan berupa angket, tes tertulis, wawancara, dan dokumentasi. Angket digunakan untuk mengetahui tipe kepribadian siswa. Angket yang digunakan dikutip dari (Littauer \& Sweet, 2016) yang disesuaikan untuk siswa menengah. Angket ini terdiri dari 40 pernyataan. Sebelum angket digunakan, angket diuji validitas menggunakan uji validitas isi setelah itu dilakukan uji coba terlebih dahulu untuk mengetahui reliabilitasnya. Pada data hasil uji coba angket yang telah dihitung menggunakan rumus KR-20 menghasilkan nilai $r_{11}=0,704$. Well dan Wollack (Azwar, 2012) menyatakan bahwa untuk tes yang digunakan di kelas oleh guru hendaknya paling tidak memiliki koefisien reliabilitas 0,70 atau lebih. Perhitungan reliabilitas pada instrumen angket tipe kepribadian ini dapat disimpulkan bahwa angket ini reliabel karena $0,704 \geq 0,70$.

Tes tertulis dalam penelitian ini digunakan untuk mengetahui sejauh mana kemampuan koneksi matematis siswa dalam menyelesaikan soal. Tes tertulis berupa dua soal uraian pada materi himpunan. Tes tertulis divalidasi dengan menggunakan validasi isi, pada instrumen ini peneliti menggunakan validitas isi aitem yang diusulkan oleh Aiken. Jika indeks kesepakatan tersebut kurang dari 0,4 maka dikatakan validitasnya rendah, di antara 0,4-0,8 dikatakan validitasnya sedang (mediocare) dan jika lebih dari 0,8 dikatakan tinggi (Retnawati, 2016). Perhitungan validasi pada instrumen tes tertulis adalah 0,667 dapat disimpulkan bahwa validitasnya sedang. Wawancara dalam penelitian ini digunakan untuk memperoleh data lisan siswa untuk memperkuat data tertulis dari tes yang telah dilaksanakan.

Dokumentasi yang digunakan dalam penelitian ini berupa lembar hasil angket, lembar jawaban soal, rekaman hasil wawancara, dan foto-foto pendukung penelitian yang lainnya. Dalam penelitian ini menggunakan triangulasi teknik, untuk pengecekan data kepada sumber yang sama dengan teknik yang berbeda yaitu dengan membandingkan hasil tes tertulis dan hasil wawancara.

\section{HASIL DAN PEMBAHASAN}

Angket kepribadian diberikan kepada 29 siswa kelas VII F SMP Negeri 22 Semarang. Kemudian diambil dua siswa, satu siswa bertipe kepribadian sanguinis dan satu siswa bertipe kepribadian melancholis. Selanjutnya adalah menganalisis kemampuan koneksi matematis berdasarkan 3 indikator, yaitu: 1) Menemukan hubungan dari berbagai representasi tentang konsep dan prosedur matematika. 2) Memahami hubungan antar topik dalam matematika. 3) Mampu menggunakan matematika dalam penyelesaian masalah dalam kehidupan sehari-hari.

\subsection{Analisis dan Pembahasan Kemampuan Koneksi Matematis Siswa Bertipe Kepribadian Sanguinis}

Gambar 1 adalah cuplikan hasil tes tertulis dan tes wawancara siswa bertipe kepribadian sanguinis pada indikator yang pertama yaitu menemukan hubungan dari berbagai representasi tentang konsep dan prosedur matematika. 

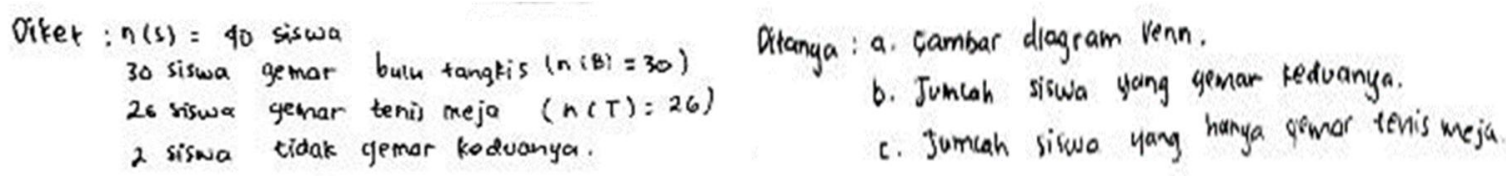

Gambar 1. Hasil Tes Tertulis Subjek Sanguinis pada Indikator ke-1.

P1 : "Aura, apakah kamu memahami permasalahan tersebut?"

S1 : "Paham."(sambil melihat soal)

P2 : "Informasi apa saja yang kamu temui dari permasalahan tersebut?"

S2 : "Diketahui 50 siswa SMP Garuda, siswa gemar bola basket ada 31, siswa gemar bermain voli ada 27, dan 5 siswa tidak gemar keduanya. Ditanyakan jumlah siswa yang gemar keduanya, jumlah siswa yang hanya gemar bermain bola basket dan gambar diagram venn sesuai ilustrasi tersebut."

Dari cuplikan hasil tes tertulis dan wawancara di atas menunjukkan bahwa subjek sanguinis mampu menuliskan unsur-unsur yang diketahui dan ditanyakan pada soal dengan benar. Hal ini sesuai dengan hasil penelitian dari Arifianti dan Ismail (2018), dimana subjek sanguinis dapat menuliskan apa saja yang diketahui dan ditanyakan pada soal.

Gambar 2 adalah hasil tes tertulis dan tes wawancara siswa bertipe kepribadian sanguinis pada indikator ke dua yaitu memahami hubungan antar topik dalam matematika.

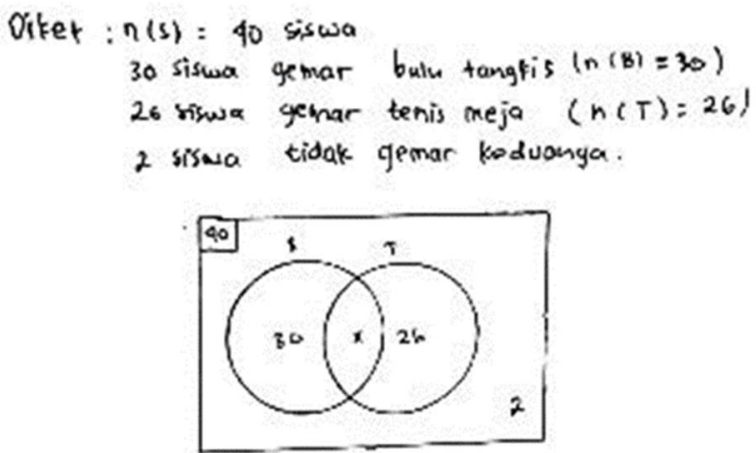

Gambar 2. Hasil Tes Tertulis Subjek Sanguinis pada Indikator ke-2.

P3 : "Bagaimana kamu menuliskan himpunan tersebut?"

S3 : "Misalnya; $n(S)=50$ siswa SMP Garuda, $n(B)=31$ adalah siswa yang gemar bermain bola basket, $n(V)=27$ adalah siswa yang gemar bermain bola voli, n(komplemen) = 5 siswa yang tidak gemar keduanya."

P4 : "Bagaimana kamu menggambarkan diagram venn tersebut?"

S4 : "Dengan menggunakan penggaris untuk menggambar persegi panjangnya dan menggunakan jangka untuk membuat lingkarannya terus mengisi datadata sesuai yang ada di ilustrasi tersebut."

P5 : "Kenapa $x$ ada di tengah lingkaran?"

S5 : "karena belum di ketahui jumlahnya."

P6 : "Kenapa 5 ada di luar lingkaran?"

S6 : "Karena yang tidak gemar keduanya." 
Dari cuplikan hasil penelitian di atas menunjukkan bahwa subjek sanguinis mampu menghubungkan unsur yang diketahui ke dalam notasi pembentuk himpunan seperti pada tes tertulis subjek menuliskan $n(S)$ untuk jumlah seluruh siswa, $n(B)$ untuk jumlah siswa yang gemar bulu tangkis dan $n(T)$ untuk jumlah siswa yang gemar tenis meja. Subjek mampu memahami konsep irisan dan komplemen dua himpunan yang disajikan dalam diagram venn seperti pada tes tertulis subjek menuliskan $x$ diantara dua lingkaran dan 2 di luar lingkaran, diperjelas dengan jawaban wawancara subjek yang menyatakan $x$ yang ada diantara dua lingkaran merupakan belum diketahui jumlahnya dan angka yang diluar lingkaran merupakan yang tidak gemar keduanya.

Gamabr 3 adalah cuplikan hasil tes tertulis dan tes wawancara siswa bertipe kepribadian sanguinis pada indikator ke tiga yaitu mampu menggunakan matematika dalam menyelesaikan masalah kehidupan sehari-hari.

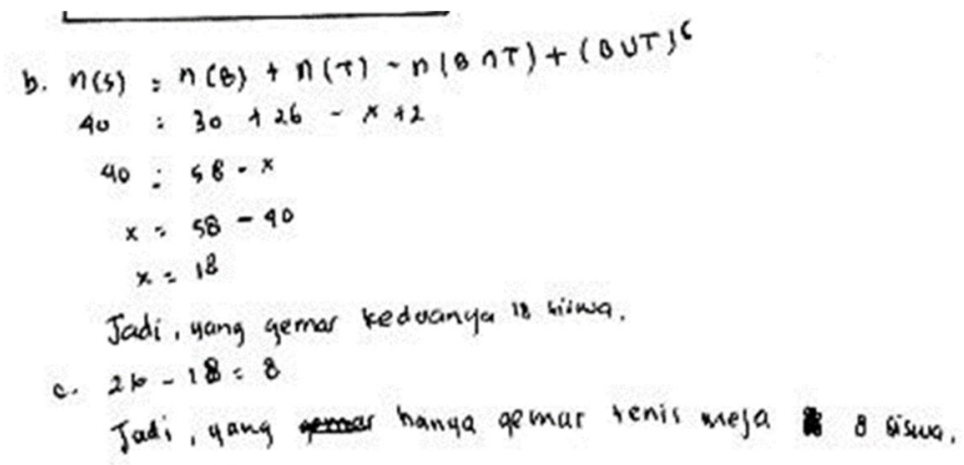

Gambar 3. Hasil Tes Tertulis Subjek Sanguinis pada Indikator ke-3.

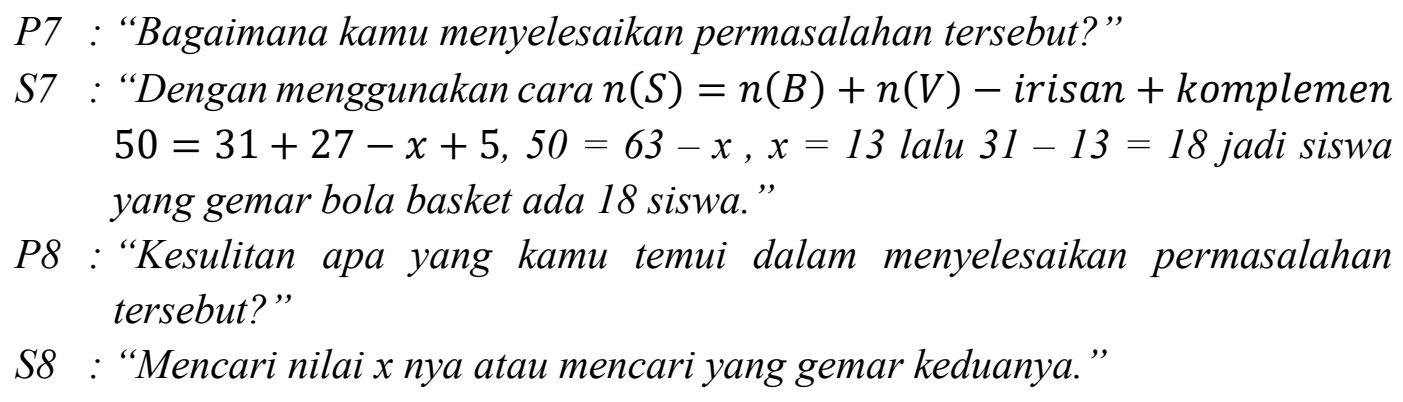

Dari cuplikan hasil penelitian di atas bahwa subjek sanguinis mampu menerapkan rumus matematika untuk menentukan banyaknya anggota irisan dua himpunan dalam menyelesaikan permasalahan kehidupan sehari-hari, dan dapat menggunakan langkah-langkah penyelesaian dengan baik serta dapat melakukan perhitungan dengan benar. Hal ini tidak sesuai dengan hasil penelitian dari Amalia dan Widodo (2019) yang menyatakan bahwa subjek sanguinis mengalami kesalahan saat melakukan proses operasi hitung. Hal ini terjadi karena pada saat pengambilan data subjek SS mampu melakukan operasi hitung dengan benar. Dalam menyelesaikan permasalahan tersebut subjek SS optimis, hal ini sesuai dengan teori Hippocrates-Galenus (Littauer \& Sweet, 2016) yang menyebutkan bahwa seseorang dengan tipe kepribadian sanguinis merupakan orang yang optimis, punya energi dan antusias.

Berdasarkan deskripsi di atas menunjukkan bahwa subjek sanguinis dalam kemampuan koneksi matematis memenuhi 3 dari 3 indikator kemampuan koneksi matematis. Dalam analisis 
ini subjek sanguinis mampu menemukan hubungan dari berbagai representasi tentang konsep dan prosedur matematika, mampu memahami hubungan antar topik dalam matematika dan mampu menggunakan matematika dalam menyelesaikan masalah kehidupan sehari-hari.

\subsection{Analisis dan Pembahasan Kemampuan Koneksi Matematis Siswa Bertipe Kepribadian Melancholis}

Gambar 4 adalah cuplikan hasil tes tertulis dan tes wawancara siswa bertipe kepribadian melancholis pada indikator yang pertama yaitu menemukan hubungan dari berbagai representasi tentang konsep dan prosedur matematika.

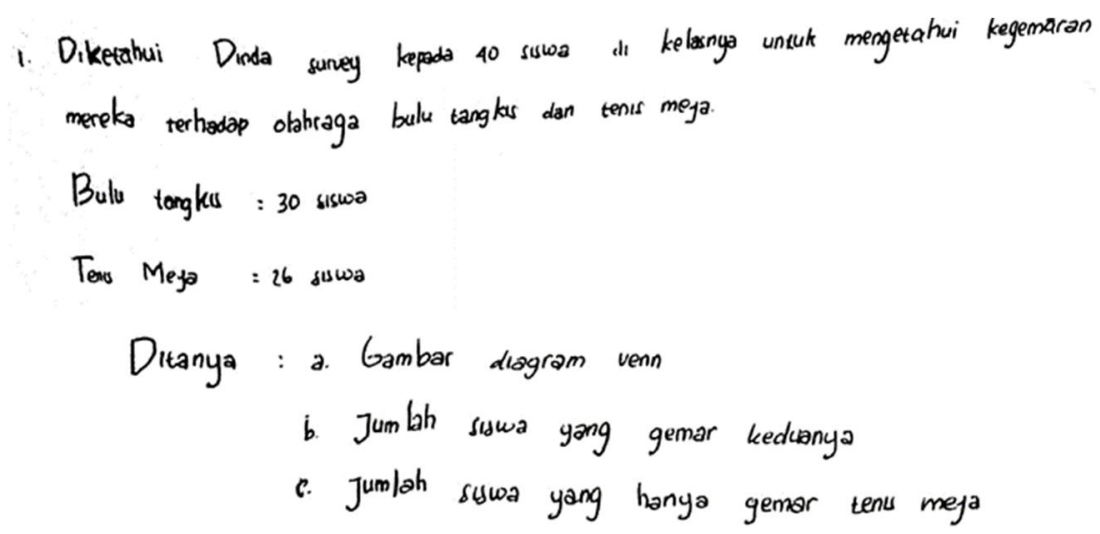

Gambar 4. Hasil Tes Tertulis Subjek Melancholis pada Indikator ke-1.

P1 : "Jihan, apakah kamu memahami permasalahan tersebut?"

MS1 : "Paham."

P2 : "Informasi apa saja yang kamu temui dari permasalahan tersebut?"

MS2 : "Diketahui Rio survei kepada 50 siswa SMP Garuda untuk mengetahui kegemaran mereka terhadap olahraga bola basket dan bola voli. Diketahui 31 siswa gemar dengan olahraga bola basket, dan 27 siswa gemar dengan olahraga bola voli. Ditanya jumlah siswa yang hanya gemar bermain basket, gambar diagram venn sesuai ilustrasi di atas, dan jumlah siswa yang gemar keduanya."

Berdasarkan cuplikan hasil peneltian di atas menunjukkan bahwa subjek melancholis mampu menemukan informasi dari permasalahan tersebut. Terlihat dari subjek mampu menyebutkan unsur-unsur yang diketahui dari permasalahan tersebut dan subjek juga mampu menyebutkan unsur yang ditanyakan dari permasalahan tersebut. Hal ini sesuai dengan hasil penelitian dari Fitria dan Siswono (2014), menyatakan bahwa siswa yang memiliki tipe kepribadian melancholis mampu menyebutkan hal-hal yang diketahui dan yang ditanyakan pada soal.

Selanjutnya, Gambar 5 adalah hasil tes tertulis dan tes wawancara siswa bertipe kepribadian melancholis pada indikator ke dua yaitu memahami hubungan antar topik dalam matematika. 

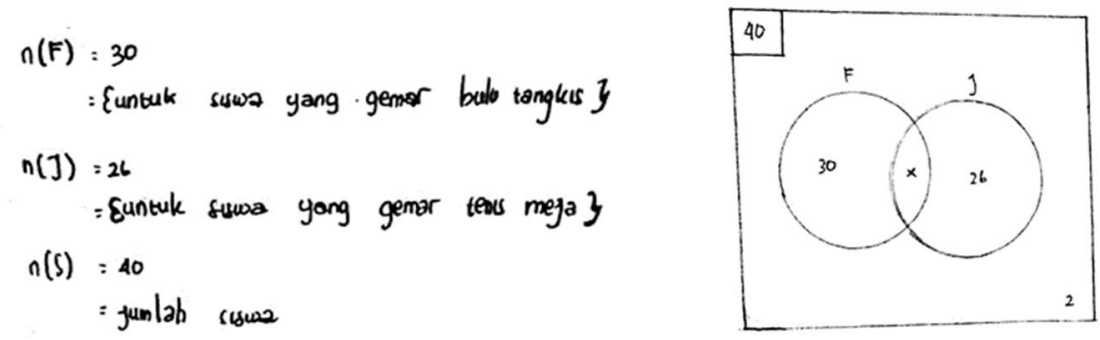

Gambar 5. Hasil Tes Tertulis Subjek Melancholis pada Indikator ke-2

P3 :"Bagaimana kamu menuliskan himpunan tersebut?"

MS3 : " $n(F)$ untuk siswa yang gemar bola basket, $n(F)=31, n(J)$ untuk siswa yang gemar bola voli, $n(J)=27$, dan $n(S)$ jumlah seluruh siswa, $n(S)=50$."

P4 : "Bagaimana kamu menggambarkan diagram venn tersebut?"

MS4 : "Pertama-tama kita membuat persegi panjang terlebih dahulu, setelah itu kita membuat 2 lingkaran yang dinamakan $F$ dan J lalu diisilah data sesuai ilustrasi di atas."

P5 : "Kenapa angka $x$ ada di tengah lingkaran?"

MS5 : "Karena x belum diketahui hasilnya."

P6 : "Kenapa 5 ada di luar lingkaran?"

MS6 : "Karena 5 adalah jumlah siswa yang tidak gemar keduanya."

Berdasarkan hasil penelitian di atas menunjukkan bahwa subjek melancholis dapat menghubungkan unsur yang diketahui kedalam notasi pembentuk himpunan seperti pada tes tertulis subjek menuliskan $n(F)$ untuk jumlah siswa yang gemar bulu tangkis, $n(J)$ untuk jumlah siswa yang gemar tenis meja, $n(S)$ untuk jumlah seluruh siswa. Subjek mampu memahami konsep irisan dan komplemen dua himpunan yang disajikan dalam diagram venn seperti pada tes tertulis subjek menuliskan $x$ diantara dua lingkaran dan angka 2 di luar lingkaran, diperjelas dengan jawaban wawancara subjek yang menyatakan bahwa $x$ berada di antara dua lingkaran belum diketahui hasilnya dan angka yang berada diluar lingkaran adalah jumlah siswa yang tidak gemar keduanya.

Gambar 6 adalah hasil tes tertulis dan tes wawancara siswa bertipe kepribadian melancholis pada indikator ke tiga yaitu mampu menggunakan matematika dalam menyelesaikan masalah kehidupan sehari-hari.

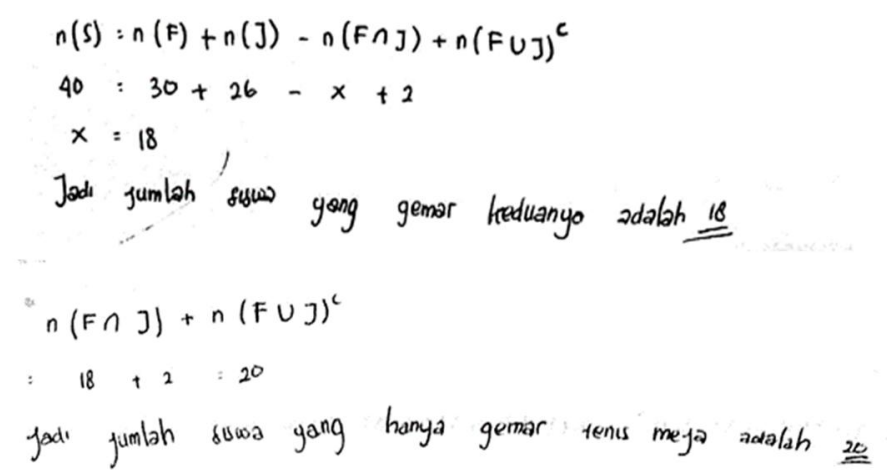

Gambar 6. Hasil Tes Tertulis Subjek Melancholis pada Indikator ke-3. 


\section{P7 : "Bagaimana kamu menyelesaikan permasalahan tersebut?" \\ MS7 : " $n(S)=n(F)+n(J)-$ irisan + komplemen, sama dengan $31+27-x+5$, sama dengan 50, $x=13$, jumlah siswa suka keduanya ada 13, irisan + komplemen $=13+5=18$, dan jumlah siswa yang suka basket ada 18 siswa." \\ P8 : "Kesulitan apa yang kamu temui dalam menyelesaikan permasalahan tersebut?" \\ MS8 : "Kesulitan pada saat mencari x karena membutuhkan langkah yang cukup banyak."}

Berdasarkan cuplikan hasil penelitian di atas menunjukkan bahwa subjek melancholis mampu menerapkan rumus matematika untuk menentukan banyaknya anggota irisan dua himpunan dalam menyelesaikan permasalahan kehidupan sehari-hari, namun ketika subjek mencari jumlah siswa yang hanya gemar salah satu olahraga kurang tepat hal ini diperjelas dengan hasil tes tertulis yang masih salah dan pada saat wawancara subjek menyatakan rumus yang digunakan yaitu irisan + komplemen. Hal ini tidak sesuai dengan hasil penelitian dari Amalia \& Widodo (2019) mengatakan bahwa subjek dengan tipe kepribadian melancholis dapat mengaplikasikan rumus dengan runtut dan benar. Hal ini dikarenakan pada saat pengambilan data subjek MS kurang tepat dalam menerapkan rumus matematika untuk menyelesaikan permasalahan tersebut.

Berdasarkan deskripsi di atas menunjukkan bahwa subjek melancholis yang memiliki tipe kepribadian melancholis dalam kemampuan koneksi matematis memenuhi 2 dari 3 indikator. Dalam analisis ini subjek melancholis mampu menemukan hubungan dari berbagai representasi tentang konsep dan prosedur matematika, mampu memahami hubungan antar topik atau konsep dalam matematika namun kurang mampu menggunakan matematika dalam menyelesaikan masalah kehidupan sehari-hari terlihat dari jawaban subjek bahwa kurang mampu dalam menerapkan rumus yang tepat.

\section{SIMPULAN}

Berdasarkan hasil penelitian dan pembahasan yang telah diuraikan, dapat disimpulkan bahwa hasil analisis kemampuan koneksi matematis siswa berdasarkan tipe kepribadian sanguinis dan melancholis dapat dijelaskan sebagai berikut. (1) Siswa sanguinis mampu memenuhi 3 dari 3 indikator kemampuan koneksi matematis, yaitu menemukan hubungan dari berbagai representasi tentang konsep dan prosedur matematika, memahami hubungan antar topik dalam matematika, dan mampu menggunkan matematika dalam penyelesaian masalah dalam kehidupan sehari-hari. (2) Siswa melancholis mampu memenuhi 2 dari 3 indikator kemampuan koneksi matematis, yaitu menemukan hubungan dari berbagai representasi tentang konsep dan prosedur matematika. Dan memahami hubungan antar topik dalam matematika.

Saran yang dapat peneliti berikan berdasarkan penelitian ini, yaitu (1) bagi guru hendaknya mampu membantu serta membiasakan siswa dalam meningkatkan kemampuan koneksi matematis untuk memecahkan suatu permasalahan matematika. (2) bagi peneliti selanjutnya yang akan melakukan penelitian sejenis terkait dengan tipe kepribadian siswa dapat dilakukan penelitian pada materi dan subjek yang berbeda. Hal ini bertujuan untuk melihat apakah sama atau tidak dengan temuan pada penelitian ini. 


\section{DAFTAR PUSTAKA}

Agustina, R., Sujadi, I., \& Pangadi. (2013). Proses Berpikir Siswa SMA dalam Penyelesaian Masalah Aplikasi Turunan Fungsi Ditinjau dari Tipe Kepribadian Tipologi HippocratesGalenus. Jurnal Pembelajaran Matematika, 1(4), 370-379.

Amalia, S. R., \& Widodo, A. A. (2019). Analisis Kemampuan Pemecahan Masalah Melalui Model PBL Berbasis Etnomatematika Ditinjau dari Tipe Kepribadian Sanguinis dan Melankholis. PRISMA, Prosiding Seminar Nasional Matematika, 2, 156 - 160.

Anthony, G., \& Walshaw, M. (2009). Characteristics of Effevtive Teaching of Mathematics : A View from the West. Journal of Mathematics Education, 2(2), 147-164.

Arifianti, V., \& Ismail. (2018). Profil Berpikir Kritis Siswa SMA dalam Pemecahan Masalah Aplikasi Turunan Fungsi Ditinjau dari Tipe Kepribadian Sanguinis dan Phlegmatis. Jurnal Ilmiah Pendidikan Matematika, 7(3), 526 - 532.

Azwar, S. (2012). Reliabilitas dan Validitas. Pustaka Pelajar.

Bulu, V. R., Budiyono, \& Slamet, I. (2015). Kesulitan Metakognisi Siswa dalam Memecahkan Masalah Matematika pada Materi Peluang Ditinjau dari Tipe Kepribadian Tipologi Hippocrates-Galenus Kelas XI MIA 1 SMA Negeri 1 Soe. Jurnal Elektronik Pembelajaran Matematika, 3(9), 970 - 984.

Fitria, C., \& Siswono, T. Y. (2014). Profil Keterampilan Berpikir Kreatif Siswa dalam Memecahkan Masalah Matematis Dintinjau dari Tipe Kepribadian (Sanguinis, Koleris, Melankolis dan Phlegmatis). Jurnal Ilmiah Pendidikan Matematika, 3(3).

Jaenudin, U. (2015). Dinamika Kepribadian (Psikodinamik). CV Pustaka Setia.

Kadir, A. (2015). Rahasia Tipe-Tipe Kepribadian Anak. Diva Press.

Lappan, G., Fey, J. T., Fitzgerald, W. M., Friel, S. N., \& Phillips, E. D. (2002). Getting to Know Connected Mathematics : An Implementation Guide. New Jersey: Prentice Hall.

Littauer, F., \& Sweet, R. (2016). Personality Plus at Work - Sukses Berkarir dengan Berbagai Karakter di Tempat Kerja. CV. Andi Offset.

Maftuh, M. S. (2015). Profil Berpikir Siswa SMA dengan Tipe Kepribadian Choleris dalam Pemecahan Masalah Matematika Ditinjau dari Perbedaan Jenis Kelamin. Tahun XI, NO. 20,8 .

Otaviana, D., \& Susiaty, U. D. (2017). Prestasi Belajar Matematika Dintinjau dari Tipe Kepribadian Siswa dalam Pembelajaran Matematika. Jurnal SAP, 2(2).

Rohendi, D., \& Dulpaja, J. (2013). Connected Mathematics Project (CMP) Model Based on Presentation Media to the Mathematical Connection Ability of Junior High School Student. Journal of Education and Practice, Vol. 4(No. 4).

Rustina, R., \& Anisa, W. N. (2018). Kontribusi Model Problem Based Learning terhadap Peningkatan Kemampuan Koneksi dan Pemecahan Masalah Matematik. Jurnal Riset Pendidikan Matematika, Vol. 1, No. 1, 9.

Saminanto, \&. K. (2015). Analysis of Mathematical Connection Ability in Linear Equation with One Variabel Based on Connectivity Theory. International Journal of Education and Research, 3(4), 262.

Warih S, P. D., Parta, I. N., \& Rahardjo, S. (2016). Analisis Kemampuan Koneksi Matematis Siswa Kelas VIII pada Materi Teorema Pythagoras. Prosiding.

Widiantara, K. S., \& Herdiyanto, Y. K. (2013). Perbedaan Intensitas Komunikasi Melalui Jejaring Sosial antara Tipe Kepribadian Ekstrovert dan Introvert pada Remaja. Jurnal Psikologi Udayana, 1(1), 106-115. 